\title{
Flowing back and forth: a coronary malformation
}

\author{
Duarte Martins, ${ }^{1}$ Cátia Costa, ${ }^{2}$ Isabel Menezes, ${ }^{1}$ Fernando Maymone Martins ${ }^{1}$
}

${ }^{1}$ Department of Paediatric Cardiology, Centro Hospitalar de Lisboa Ocidental EPE, Lisboa, Portugal

${ }^{2}$ Hospital Santarém, Santarém, Portugal

\section{Correspondence to} Dr Duarte Martins,

duartesaraivamartins@gmail. com

Accepted 26 June 2017
To cite: Martins D, Costa $C_{\text {, }}$ Menezes I, et al. BMJ Case Rep Published Online First: [please include Day Month Year]. doi:10.1136/bcr-2017221360

\section{DESCRIPTION}

This beautiful angiogram was obtained from an asymptomatic healthy 14-year-old male. Undergoing cardiovascular evaluation for sport practice, he had a normal physical examination except for a grade II low frequency murmur. Serial otherwise unremarkable ECGs revealed frequent monomorphic ventricular ectopy, which increased in frequency during an asymptomatic treadmill stress test. His echocardiogram showed a normal left ventricular systolic function with minimal anterolateral hypokinesia and an abnormal diastolic septal flow on colour Doppler. Cardiac MRI portrayed basal anterolateral myocardial fibrosis and marked ectasia of the right coronary artery (RCA), although fine coronary anatomic definition was not possible due to motion artefact. With the clinical suspicion of a coronary fistula, conventional angiography was preferred over CT for its eventual therapeutic purpose. The angiogram (figure 1, video 1) demonstrated a severely dilated RCA feeding a dense net of collaterals, which drained retrogradely into the left coronary artery (LCA) with diastolic run-off into the main pulmonary artery, diagnosing and demonstrating the pathophysiological mechanism of an anomalous LCA from pulmonary artery. This rare entity often presents as ischaemic cardiomyopathy in early infancy as the physiological drop in pulmonary vascular resistance precipitates inadequate perfusion of the LCA.

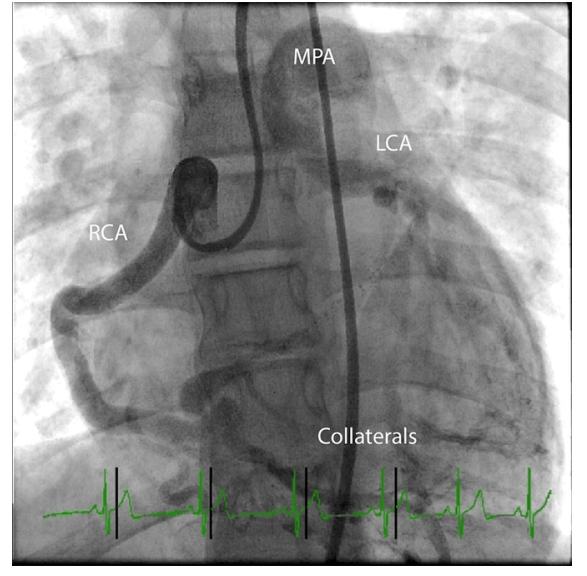

Figure 1 Composite image of a selective RCA of ALCAPA. ALCAPA, anomalous left coronary artery from pulmonary artery; LCA, left coronary artery; MPA, main pulmonary artery; RCA, right coronary angiogram.

However, increasing numbers of adolescent and adult cases have been described, ${ }^{1}$ with a more benign early course due to abundant collateral circulation, presenting later in life with exercise intolerance, ventricular dysrhythmias and sudden cardiac death due to coronary steal. ${ }^{2}{ }^{3}$ Surgical reimplantation

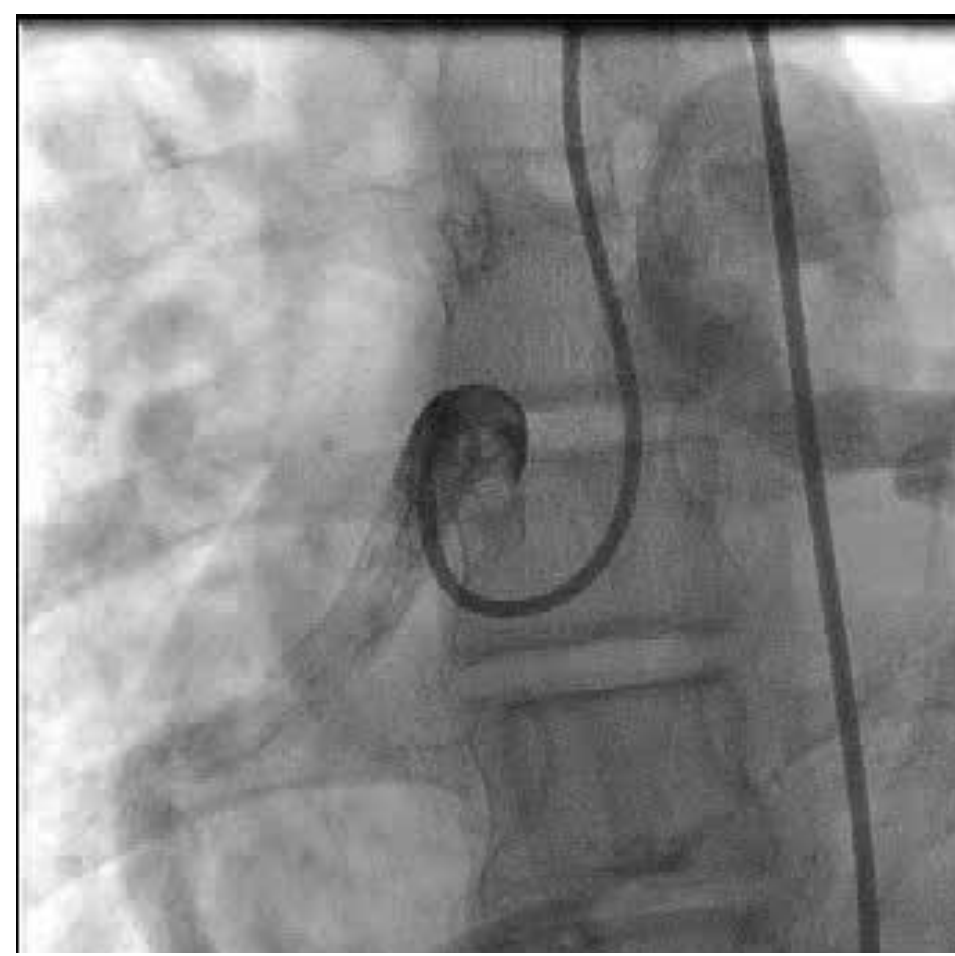

Video 1 Selective Right Coronary Angiogram of ALCAPA. 


\section{Learning points}

- Anomalous left coronary artery from pulmonary artery is a congenital malformation with a varied spectrum of presentation depending of the presence and amount of coronary collaterals.

- In the setting of abundant coronary collaterals, the patient may have a more benign early course reaching adulthood with no or little symptoms and yet at a preventable risk for ventricular dysrhythmias and sudden cardiac death due to coronary steal.

- Diagnosis may be elusive and should be considered.

of the LCA into the Aorta was successfully performed, with an uneventful postoperative period.

Contributors All authors contributed to the manuscript as follows: DM, CC, FMM: conception, design, analysis and interpretation of data. DM: drafting the article. IM,
FMM; revising it critically for important intellectual content. DM, CC, IM, FMM: final approval of the version to be published. All authors read and approved the final manuscript.

Competing interests None declared.

Patient consent Obtained.

Provenance and peer review Not commissioned; externally peer reviewed.

(C) BMJ Publishing Group Ltd (unless otherwise stated in the text of the article) 2017. All rights reserved. No commercial use is permitted unless otherwise expressly granted.

\section{REFERENCES}

1 Yau JM, Singh R, Halpern EJ, et al. Anomalous origin of the left coronary artery from the pulmonary artery in adults: a comprehensive review of 151 adult cases and a new diagnosis in a 53-year-old woman. Clin Cardiol 2011;34:204-10.

2 Liu Y, Miller BW. ALCAPA presents in an adult with exercise intolerance but Preserved cardiac function. Case Rep Cardiol 2012;2012:1-3.

3 Kristensen T, Kofoed KF, Helqvist $S$, et al. Anomalous origin of the left coronary artery from the pulmonary artery (ALCAPA) presenting with ventricular fibrillation in an adult: a case report. J Cardiothorac Surg 2008;3:33.

Copyright 2017 BMJ Publishing Group. All rights reserved. For permission to reuse any of this content visit http://group.bmj.com/group/rights-licensing/permissions.

BMJ Case Report Fellows may re-use this article for personal use and teaching without any further permission.

Become a Fellow of BMJ Case Reports today and you can:

- Submit as many cases as you like

- Enjoy fast sympathetic peer review and rapid publication of accepted articles

- Access all the published articles

- Re-use any of the published material for personal use and teaching without further permission

For information on Institutional Fellowships contact consortiasales@bmjgroup.com

Visit casereports.bmj.com for more articles like this and to become a Fellow 